\title{
Effect of Age of Roots on Yield for Canning Purposes, Chemical Composition of Raw Roots, and Quality of Canned Product of Cobre and U.P.R.3 Sweetpotatoes
}

\author{
M. A. González, J. R. Benero, and F. Sánchez Nieva ${ }^{1}$
}

\section{INTRODUCTION}

U. S. Standards for grades $(1)^{2}$ establish the following main styles for syrup-packed canned sweetpotatoes: Whole, pieces, or a combination of the two. It has been generally recognized by processors that a better quality pack can be obtained when whole sweetpotatoes are processed. Woodroof et al. (2), in their study of the canning of sweetpotatoes, found that canning them whole was desirable, since sweetpotatoes too small to be marketed otherwise could be utilized, and besides, canned whole sweetpotatoes remained more solid, and the syrup remained clearer than when they were cut. Canning of whole sweetpotatoes offers the additional advantage that the product can be sold at a higher price and is preferred by consumers.

Sweetpotatoes to be canned whole must be of such size and weight that the specified requirements for drained weight can be met. Although sweetpotatoes have been grown commercially in Puerto Rico for many years, no information is available on the yields for canning purposes that can be obtained from the available commercial varieties.

The size of the sweetpotato depends mainly on the varietal characteristics, differing seasonal and soil conditions, and the age of the root at the time of harvesting when recommended agronomical practices are used. Moscoso (3) reported yields of sweetpotatoes obtained from several varieties, but these figures were based on harvesting $41 / 2$ months after planting. No information is available on the yields of the different sizes of sweetpotatoes that may be obtained when harvested at different ages.

Since the success of any commercial operation in the processing of agricultural commodities generally depends on producing the product at a reasonable profit to the processor, as well as on production on the farm with yields large enough to afford farmers an adequate income, it was felt

${ }^{1}$ Assistant Chemical Engineer, Assistant Chemist, and Technical Director, respectively, of the Food Technology Laboratory of the Agricultural Experiment Station, University of Puerto Rico, Río Piedras, P.R. The authors wish to extend their most sincere appreciation to the Food Technology staff members who aided in the chemical analyses as well as in the organoleptic appraisals of the canned sweetpotatoes.

Italic numbers in parentheses refer to Literature Cited, p. 264. 
necessary to determine the yields of sweetpotatoes of canning grade that could be obtained when dug at different ages.

\section{EXPERIMENTAL PROCEDURE}

Two varieties of sweetpotatoes, Cobre and U.P.R.3, were planted at the Gurabo Substation. Methods of soil preparation, fertilizer applications, insect control, time of planting, and harvesting were carried out as recommended by Moscoso ( 8 ).

The sweetpotatoes were planted during September, October, and December. Each planting consisted of three blocks, arranged in a randomized complete block design with each test containing four replications. The sweetpotatoes were harvested 120,135 , and 150 days after planting, weighed, and graded for size. Only roots ranging in size from $11 / 2$ to 2 inches in diameter, corresponding to U. S. Grade No. 1, were processed. Processing was carried out as soon as possible after digging.

The sweetpotatoes were processed as described by Sánchez et al. (4). The roots were washed in a rotary washer and peeled in 10-percent lye at $210^{\circ} \mathrm{F}$. From the lyepeeler the roots were discharged into a rotary-washer provided with high-pressure water sprays to remove lye and loose peelings. Trimming immediately followed peeling and washing. The roots were kept under water before and after trimming to prevent discoloration. The sweetpotatoes were packed in a plain tin can with C-enameled ends; 14-ounce fill-in-weight No. 2 cans was used.

Thirty-five-degree brix syrup at $200^{\circ} \mathrm{F}$. was added and the cans were exhausted in a steam exhaust-box for 15 minutes to a center-can temperature of $165^{\circ} \mathrm{F}$. After closing, the cans were retorted for 45 minutes at $240^{\circ} \mathrm{F}$. and cooled to $100^{\circ} \mathrm{F}$. The cooled cans were air-dried and stored at room temperature $\left(85^{\circ} \mathrm{F}\right.$.).

\section{ANALYTICAL METHODS}

Roots were sampled and analyzed by the procedures recommended by Sánchez et al. (4).

\section{ORGANOLEPTIC TESTS}

The quality of the canned product was determined organoleptically by trained tasters from our own staff. The pair and the hedonic-scale methods were used to determine product preference and quality.

Samples of canned sweetpotatoes from which the liquor had been drained were presented to the tasters in an air-conditioned booth under red light. The color of the samples was scored under daylight.

In the pair-test samples of each variety harvested at 120,135 , and 150 days after planting were compared with each other. Each pair was presented to the tasters, and they were requested to taste both samples and to 
indicate their preferences on the basis of tenderness, flavor, color, and appearance. Differences between the samples were determined by statistical analysis of the data.

In the hedonic-scale method of measuring food preference, a 9-point scale expressed in terms of "like" and "dislike" was used to determine tasters' preference for flavor and color. Single samples were presented to the tasters under red light, and each sample was tasted and rated before the next was served. The sample for color determination was served under daylight.

\section{RESULTS}

EFFECT OF TIME OF DIGGING ON YIELD OF SWEETPOTATO FOR CANNING AS WHOLE

The time of digging was found to have a direct effect on the yield of sweetpotatoes of size corresponding to U. S. Grade No. 1 for canning pur-

TABLE 1.-Percentage yields as percentage of tolal yield of sweetpolatoes of different sizes obtained from Cobre and U.P.R.S varieties when harvested 120, 185 , and 150 days after planting

\begin{tabular}{c|c|c|c|c|c|c|c|c}
\hline \multirow{2}{*}{ Days after planting } & \multicolumn{3}{|c|}{$\begin{array}{c}\text { Percentage yield of indicated size } \\
\text { (inches) for Cobre }\end{array}$} & \multicolumn{3}{c}{$\begin{array}{c}\text { Percentage yield of indicated } \\
\text { size (inches) for U.P.R.3 }\end{array}$} \\
\cline { 2 - 6 } & $11 / 2$ & $11 / 2-2$ & $2-21 / 2$ & $21 / 2$ & $11 / 2$ & $11 / 2-2$ & $2-21 / 2$ & $21 / 2$ \\
\hline 120 & 30.015 & 67.570 & 2.265 & 0.15 & 19.89 & 69.35 & 8.10 & 2.66 \\
135 & 20.635 & 72.095 & 6.43 & .84 & 15.67 & 70.66 & 10.18 & 3.49 \\
150 & 18.36 & 75.79 & 4.04 & 1.81 & 12.49 & 71.29 & 11.35 & 4.87 \\
\hline
\end{tabular}

poses, that is, within a diameter of $11 / 2$ to 2 inches, and not more than 5 inches in length. Yields of each size of sweetpotato obtained at different times of digging, in terms of percentage of the total overall yield of sweetpotatoes obtained are given in table 1 . These results show that the percentage of sweetpotatoes corresponding to U. S. Grade No. 1 increased with age, reaching a maximum when the sweetpotatoes were dug 150 days after planting. When sweetpotatoes of the U.P.R. 3 variety were planted during September, an average yield of 1,922 pounds per acre was obtained when dug 120 days after planting; 3,127 after 135 days; and 3,493 after 150 days. The yields for the Cobre variety likewise increased with time, reaching a maximum of 8,143 pounds per acre 150 days after planting.

\section{COMPOSITION OF UNPROCESSED ROOTS}

The analytical data on samples of raw roots are given in table 2. These values represent the average of three analyses. The results show that the chemical composition of the tubers of Cobre and U.P.R.3 varieties does not 
change greatly with the age of the sweetpotatoes, except for vitamin $\mathbf{C}$, which decreases as the tubers grow older. Ezell et al. (6) also found that there is a decline in ascorbic acid as the roots grow older. The rate of decline differs among varieties. These results are also in agreement with the findings of Cochran et al. (5) who showed that there is no such thing as maturity in sweetpotatoes, and of Ezell et al. (6) who reported that sweetpotatoes may be harvested at any time after they reach marketable size.

TABLE 2.-Chemical composition of raw roots of Cobre and U.P.R.S sweetpotato varieties expressed on wet basis; average figures from $S$ analyses when harvested 120,185 , and 150 days afler planting

\begin{tabular}{|c|c|c|c|c|c|c|}
\hline \multirow{2}{*}{ Characteristic measured } & \multicolumn{3}{|c|}{ Cobre variety harvested at- } & \multicolumn{3}{|c|}{ U.P.R.3 variety harvested at- } \\
\hline & 120 days & 135 days & 150 days & 120 days & 135 days & 150 days \\
\hline Moisture ........ percent & 72.0 & 73.50 & 71.26 & 70.60 & 68.53 & 67.35 \\
\hline Total acidity.... do. & .1317 & .134 & .152 & .1423 & .1277 & .1425 \\
\hline Reducing sugars.. do. & 1.66 & 1.12 & 1.43 & .472 & .67 & .485 \\
\hline Total sugars as invert. do. & 3.986 & 4.169 & 4.50 & 3.675 & 3.55 & 4.336 \\
\hline Starch......... do. & 21.21 & 22.69 & 22.69 & 24.20 & 21.11 & 21.625 \\
\hline Vital C......mg./100 gm. & 36.64 & 34.89 & 29.78 & 30.15 & 24.15 & 23.16 \\
\hline B carotene...mg./100 gm. & 7.24 & 9.764 & 7.859 & 11.198 & 10.08 & 11.27 \\
\hline Specific gravity & 1.054 & 1.029 & 1.089 & 1.0296 & 1.041 & 1.030 \\
\hline Hunter color & & & & & & \\
\hline$R d$ & 47.98 & 44.38 & 41.52 & 41.64 & 41.64 & 43.12 \\
\hline$a$ & 19.80 & 24.80 & 22.85 & 27.10 & 28.78 & 28.85 \\
\hline $\boldsymbol{b}$ & 24.29 & 28.45 & 27.70 & 29.62 & 30.27 & 31.16 \\
\hline
\end{tabular}

\section{PROCESSING CHARACTERISTICS}

EFFECT OF AGE OF TUBER ON PEELING AND TRIMMING LOSSES

A 10-percent lye solution at $210^{\circ} \mathrm{F}$. for about 6 minutes was used to peel the sweetpotatoes from both varieties. The sweetpotatoes from both varieties and of different ages were easy to peel. After lye-peeling it was very easy to remove all rags and excess lye from the roots by washing with water sprays in a rotary washer.

The percentage of peeling losses, trimming losses, and overall yield are shown in table 3. Statistical analysis of the data indicates that no difference could be found in the recovery of roots for canning purposes, after peeling and trimming, for sweetpotatoes of the same variety harvested at different times during the season.

SYRUPING, EXHAUSTING, AND COOKING

The age of the root had no effect on discoloration during processing for the two varieties tested. Exhausting for 14 minutes to a can-center tempera- 
ture of 160 to $165^{\circ} \mathrm{F}$. was found adequate to insure a good vacuum in the can. All packs prepared in the course of this work were processed for 45 minutes at $240^{\circ} \mathrm{F}$., according to the conditions recommended by Sánchez et al. (4).

\section{QUALITY OF THE CANNED PRODUCT}

In the results of the organoleptic test using the pair test to determine the difference in tenderness, flavor, color, and appearance, and the hedonic scale to indicate the tasters' preference for color and flavor of the processed roots, no significant difference could be found in the sweetpotatoes of the same variety at different ages. It can be concluded that the quality of the syrup-packed sweetpotatoes of the Cobre and U.P.R3 varieties is essentially the same when the roots are dug from 120 to 150 days after planting, when

TABLE 3.-Percentage peeling, trimming, and root recovery for raw roots of Cobre and U.P.R.S sweetpotato varieties; average figures from $\$$ runs when harvested 120,185 , and 150 days after planting

\begin{tabular}{l|c|c|c|c|c|c}
\hline \multirow{2}{*}{ Characteristic } & \multicolumn{5}{|c}{ Results when harvested after the number of days indicated } \\
\cline { 2 - 7 } & 120 & 135 & 150 & 120 & 135 & 150 \\
\hline Peeling loss & 32.15 & 27.21 & 30.25 & 26.90 & 29.06 & 30.13 \\
Trimming loss & 13.99 & 13.51 & 12.56 & 16.09 & 14.30 & 17.34 \\
Recovery of roots for & 53.86 & 59.28 & 57.19 & 57.01 & 56.64 & 53.35 \\
canning purposes & & & & & & \\
\hline
\end{tabular}

only roots from $11 / 2$ to 2 inches in diameter, and not more than 5 inches in length, are used for canning purposes.

These results show that there is no such thing as maturity in sweetpotatoes. The age of tubers affects only the overall yield and the yield for canning purposes; it does not significantly affect the chemical composition, processing characteristics, or quality of the canned product.

\section{SUMMARY}

The effect of age of tubers on the yield for canning of whole sweetpotatoes corresponding to U. S. Grade No.1, the chemical composition of the raw roots, and the quality of the canned product were studied for the Cobre and U.P.R.3 varieties of sweetpotatoes. The greatest overall yields and the maximum yields for canning purposes, were obtained in both varieties by harvesting 150 days after planting. It was observed that the age of tubers had no effect on the chemical composition of the raw root, its behavior during processing, or the quality of the canned product. 


\section{RESUMEN}

Se estudió el efecto de la edad de la batata al cosecharse, su rendimiento para enlatar cuando alcanzan un diámetro de $1 \frac{1}{2}$ a 2 pulgadas, cambios en la composición química del tubérculo en su estado natural, y también su efecto sobre la calidad del producto enlatado. Estos experimentos se hicieron utilizando las variedades Cobre y U.P.R.3.

Se encontró además que para el enlatado, estas variedades rinden más cuando se cosechan después de los 150 días de sembradas. También se comprobó que la edad no afecta mayormente la composición química de las variedades Cobre y U.P.R.3, en su estado natural, ni tampoco su comportamiento mientras dura el proceso de enlatado, ni la calidad final del producto elaborado.

\section{LITERATURE CITED}

1. The Almanac, pp. 229-30, Edward E. Judge, P.O. Box 248, Westminister, Md., 1960.

2. Woodroof, J. G., Du Preé, W. E., and Cecil, S. R., Canning Sweet Potatoes, pp. 40, Ga. Agr. Exp. Sta., Bul. N.S. 12, 1955.

3. Moscoso, C., El Cultivo de la Batata en Puerto Rico, pp. 48, Agr. Exp. Sta., Univ. P.R., Bul. 126, 1955.

4. Sánchez-Nieva, F., Benero, J. R., and González, M. A., A Comparison of the canning quality of the Rico and the U.P.R.3 sweetpotatoes, J. Agr. Univ. P.R. 42 (4) 224-32, 1958.

5. Cochran, F. D., Collins, E. R., Covington, H. M., Ellis, H. M., Garris, G. D., Nielsen, L. E., and Ritcher, P., Growing Quality Sweet Potatoes, pp. 13, N.C. Agr. Ext. Serv., Ext. Circ. 353, 1950.

6. Ezell, B. D., Welcox, M. S., and Crowder, J. N., Pre- and postharvest changes in corotene, total corotenoids and ascorbic acid content of sweetpotatoes, Plant Physiol. 27 355-69, 1952. 